\title{
Eric Fougère, Les paravents de Mme Chrysanthème ou l'impossible Loti
}

\section{Ida Merello}

\section{Q OpenEdition}

1 Journals

\section{Edizione digitale}

URL: http://journals.openedition.org/studifrancesi/33526

DOI: 10.4000/studifrancesi.33526

ISSN: 2421-5856

\section{Editore}

Rosenberg \& Sellier

\section{Edizione cartacea}

Data di pubblicazione: 1 décembre 2005

Paginazione: 670

ISSN: 0039-2944

Notizia bibliografica digitale

Ida Merello, «Eric Fougère, Les paravents de Mme Chrysanthème ou l'impossible Loti», Studi Francesi [Online], 147 (XLX | III) | 2005, online dal 30 novembre 2015, consultato il 20 avril 2021. URL: http:// journals.openedition.org/studifrancesi/33526 ; DOI: https://doi.org/10.4000/studifrancesi.33526

Questo documento è stato generato automaticamente il 20 avril 2021.

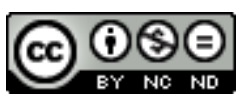

Studi Francesi è distribuita con Licenza Creative Commons Attribuzione - Non commerciale - Non opere derivate 4.0 Internazionale. 


\title{
Eric Fougère, Les paravents de Mme Chrysanthème ou l'impossible Loti
}

\author{
Ida Merello
}

\section{NOTIZIA}

ERIC FOUGÈRE, Les paravents de Mme Chrysanthème ou l'impossible Loti, «Revue d'histoire littéraire de la France, Paris, P.U.F, oct.-dec. 2004, 104e année, nº 4, pp. 905-918.

1 L'A. prende in considerazione l'amore per il giapponismo di Loti, ben distinto dall'amore per il Giappone e contraddistinto dal piacere per una rappresentazione manierata che investe tutta la realtà riducendola a elementi decorativi e miniaturizzati: personaggi compresi, dotati di grazia, ma anche manierati e leziosi. Così in Mme Chrysanthème, che pure presenta delle analogie sul piano dell'intreccio con il triangolo sentimentale di Aziyadé, il desiderio sessuale del protagonista nei confronti della propria compagna appare una semplice manifestazione dell'attrazione nei confronti di un sistema di elementi giapponesizzanti; mentre l'amore -omosessuale- scatta nei confronti del rivale. Secondo l'A. Loti è perfettamente consapevole del proprio compiacimento per gli stereotipi, e condivide l'ironia dei critici nei confronti delle proprie finzioni, in quanto il desiderio di derisione è appunto il nucleo centrale del romanzo. 